\title{
A CRITICAL REVIEW ON SHORT TERM IMPACT OF DEMONETISATION ON INCLUSIVE GROWTH OF INDIA
}

\author{
Dixit Pankaj, Assistant Professor, Research scholar \\ Department of Accounting and Finance, Lebanese French University, Erbil, Kurdistan, Iraq \& \\ Department of Commerce and Business Administration, M.M. College Modinagar, \\ C.C.S. University Meerut, India
}

\author{
Al-kake Farhad, Head of Department \\ Department of Accounting and Finance, Lebanese French University, Erbil, Kurdistan, Iraq
}

\author{
Ahmed Ramyar Rzgar, Dean \\ College of Business Administration and Economics, Lebanese French University, Erbil, \\ Kurdistan, Iraq \\ *E-mail: pdixit2989@gmail.com
}

\begin{abstract}
In this paper, we focused on the impact of demonetisation on unorganized sector by which the inclusive growth of our country falls down. All the research and study shows that the inclusive growth of India has been affected in short run after decision implemented by the Govt. of India. GDP growth has been pegged at 7\% in quarter ending December 2016, while the growth for 2016-17 has been estimated at 7.1\%. This is in various estimates, including the International Monetary fund's report reveals that the growth of manufacturing sector will be decline in next quarter; CSO reports also depict the picture of GDP's downturn trend of manufacturing sector. The researchers also analyse the data and find that demonetisation affected the inclusive growth due to which the people engaged in unorganised sector loosed their jobs. The Government of India announced that the Rs 500 and Rs. 1000 denominated currency notes will cease to be legal tender. The move was targeted towards tackling inclusive growth, unorganized sectors and black money. After initial euphoria, questions began to emerge that the government of our country still does not have the proper report of unorganized sector's data as the government has answerable machinery. But the demonetisation may be good for the organized sector of the India economy.
\end{abstract}

\section{KEY WORDS}

Demonetisation, digitalization, unorganized sector, inclusive growth, GDP.

Indian economy, unorganized sector and Demonetisation: Most people in India earn a livelihood by working for an income. They work for one employer or many, or as selfemployed or own account workers or as contract workers, home-based workers etc. in every sector in the economy. The Unorganized sector constitutes largest portion of the economy in terms of value addition, savings, investments etc. The share of organized sector is around 12-14 percent in our national income. In the case of United States, the share of organized sector is nearly 70 percent and the population of U.S. is approx. 42 crore, which is less than as compared to 125 crore population of India. So that is the main reason behind the dependence of Indian Economy on unorganized sector. The unorganized sector's organisations are major players in such activities as manufacturing, agriculture, construction, transport, trade, hotels and restaurants, and business and personal services.

The unorganized sector plays a significant role in the economy in terms of employment opportunities and poverty alleviation. This sector generates income-earning opportunities for a large number of people. In India, a large section of the total workforce is still in the unorganized sector, which contributes a sizeable portion of the country's net domestic product. 
The economy of India is the sixth-largest economy in the world measured by nominal GDP $^{1}$ and the third-largest by purchasing power parity (PPP). And the outlook for short-term growth is also good as according to the IMF, the Indian economy is the "bright spot" in the global landscape. It adversely affects the unorganized sector due to demonetisation.

Demonetisation $^{2}$ is the act of stripping a currency unit of its status as legal tender. It occurs whenever there is a change of national currency: The current form or forms of money is pulled from circulation and retired, often to be replaced with new notes or coins. Sometimes, a country completely replaces the old currency with new currency. The opposite of demonetisation is remonetisation, in which a form of payment is restored as legal tender.

Although the history of demonetisation in India from the time when various rulers ruled over this country:

- On $12^{\text {th }}$ January 1946, Rs.500, Rs.1000 and Rs.10, 000 notes were declared as invalid as legal tender;

- The new notes of Rs.1000, Rs.5000 and Rs.10, 000 came into economy in 1954;

- On $16^{\text {th }}$ January 1978 , at that time the finance minister was H.M. Patel. The Morarji Desai led-Janta party demonetized bank notes of Rs.1000, Rs.5000 and Rs.10, 000;

- To control the flow of inflation RBI introduce a new bank note of Rs.500 into the economy in 1987;

- The current impact of demonetisation on our country on $8^{\text {th }}$ November 2016 , the old bank notes of Rs.500 and Rs.1000 were banned from being legal tender and new notes of Rs. 2000 were launched in 10th November.

The legal basis for the order demonetizing currency can be found in section-26 of the Reserve Bank of India Act 1934. Under sub section (2) of this section, the union government is given the power to declare that any notes issue by the Reserve bank will no longer be legal tender.

Many countries have experimented with the process of demonetisation in the past. Some countries benefited tremendously from the move while some terribly failed at it. Here it is a list of some countries that have implemented the policy of demonetisation:

- U.S. (1969);

- Britain (1971);

- France;

- Myanmar (1987);

- Congo (1990);

- Australia (1996);

- Zimbabwe;

- North Korea (2010);

- Pakistan (2015).

Short term impact of Demonetisation on Inclusive Growth (IG) ${ }^{3}$. The purpose of this paper is to define the impact of demonetisation on Inclusive Growth. Rapid poverty reduction requires inclusive growth that allows people to contribute to and benefit from economic growth. The statement is in line with the OECD ${ }^{4}$ development assistance committee policy statement on pro-poor growth. The inclusive growth approach takes a longer term prospective on productive employment rather on direct income redistribution, as a means of increasing incomes for excluded groups. In the short term, government could use income distribution schemes to reduce the negative impact of policies on the poors for their growth and development, but the government scheme can't be an answerable in the long term and can be problematic also in the short term. In poor countries such scheme can impose significant burden on unorganized sectors also, and it is theoretically impossible to reduce poverty through redistribution in countries where average income falls below US $\$ 700$ per

\footnotetext{
${ }_{2}^{1}$ http://statisticstimes.com/economy/countries-by-projected-gdp.php

${ }^{2}$ http://debtdiagnosis.com/2016/12/06/demonetisation-is-the-act-of-stripping-a-currency-unit-of-its-status-as-legal-tender/

${ }^{3}$ http://siteresources.worldbank.org

${ }^{4}$ http://www.oecd.org/inclusive-growth/about/inclusive-cities-campaign/all-on-board-for-inclusive-growth-in-cities-remarks-athabitat-iii.htm
} 
day. According to a recent OECD study, even in developed countries, redistribution schemes can't be the only response to rising poverty rates in certain segment of the population. Mainly the demonetisation in the country deals with the distribution of income among the unorganized sectors. Policies for inclusive growth are an important component of most government strategies for sustainable growth.

Unorganized sectors ${ }^{5}$. India's workforce comprises nearly 86 per cent in the unorganised segment, while only one-fifth of the non-farm workers are found in the organized segment.

The unorganised sector covers most of the rural labour and a substantial part of urban labour. It includes activities carried out by small and family enterprises, partly or wholly with family labour. In this sector wage-paid labour is largely non-unionised due to casual and seasonal nature of employment and scattered location of enterprises, the contributions made by the unorganised sector to the national income, is very substantial as compared to that of the organised sector. It adds more than $60 \%$ to the national income while the contribution of the organised sector is almost half of that depending on the industry. Due to the, Demonetisation the inclusive growth of the unorganized sector falls down rapidly.

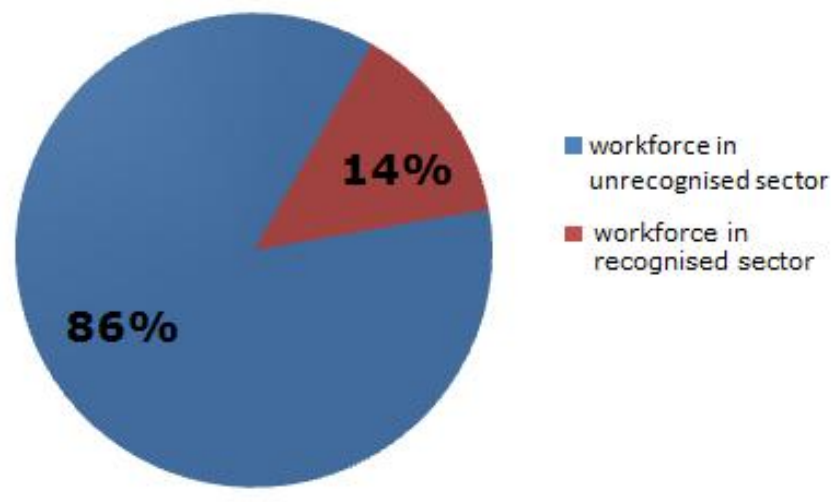

Figure 1 - Share of organised and unorganised workers in total workforce of 456,5 millions

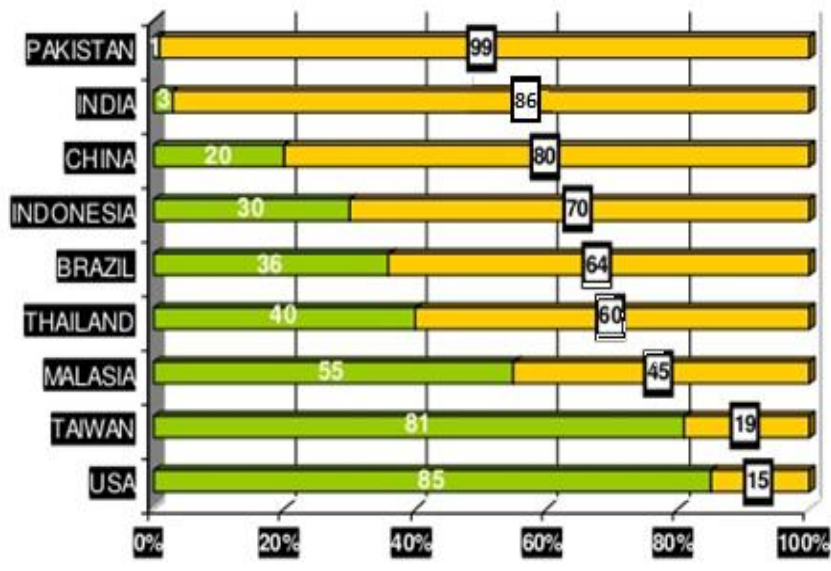

Figure 2 - Workforce by countries

On the above figure, our country which bifurcate the sectors of Indian economy as unorganized and organized sectors. We took the above data of different countries and we found that there is $99 \%$ unorganized sector in Pakistan. On the other hand, India has the second largest unorganized sector in the world.

Impact of demonetisation on inclusive growth. The unorganized sector in India will be the worst hit by the November demonetisation of high value currency. Under the organized

\footnotetext{
${ }^{5}$ http://economictimes.indiatimes.com/jobs/why-93-of-indias-workforce-is-trapped-in-unorganizedsector/articleshow/16915839.cms
} 
sectors, most of the industries were gone through the shortage of cash which is required to run the business. "The unorganized sector is expected to bear higher brunt of demonetisation". Centrum Wealth Research6 said in a report. In this matter, Centrum said results for the 3rd quarter ending December have become irrelevant post-demonetisation. "In the post-demonetized India, investors would be more focused on the subsequent quarterly (March2017) season. Quarter four 2016-17 earnings season would be a real barometer of underlying economic recovery, as it would have the full quarter impact of demonetisation, "it said. On November 8, the government announced that Rs.1, 000 and Rs.500 notes were no longer legal tender, saying the move was aimed against black money counterfeit currency and terror financing.

Data collection and analysis ${ }^{7}$. In this research paper we collect the qualitative primary data and secondary data through the reliable sources of ground reality and authentic reports of government institutions. We took the secondary data from the western U.P. and took a survey of demographic analysis, we asked many questions from almost 1000 people and they said that, they were not satisfied from the decision of demonetisation because of many reasons such as the workers and labourers found difficulties because they lose their jobs. The primary data collect from Meerut, Ghaziabad and Muzaffarnagar had also focused on the data analysis regarding the adverse impact of demonetisation.

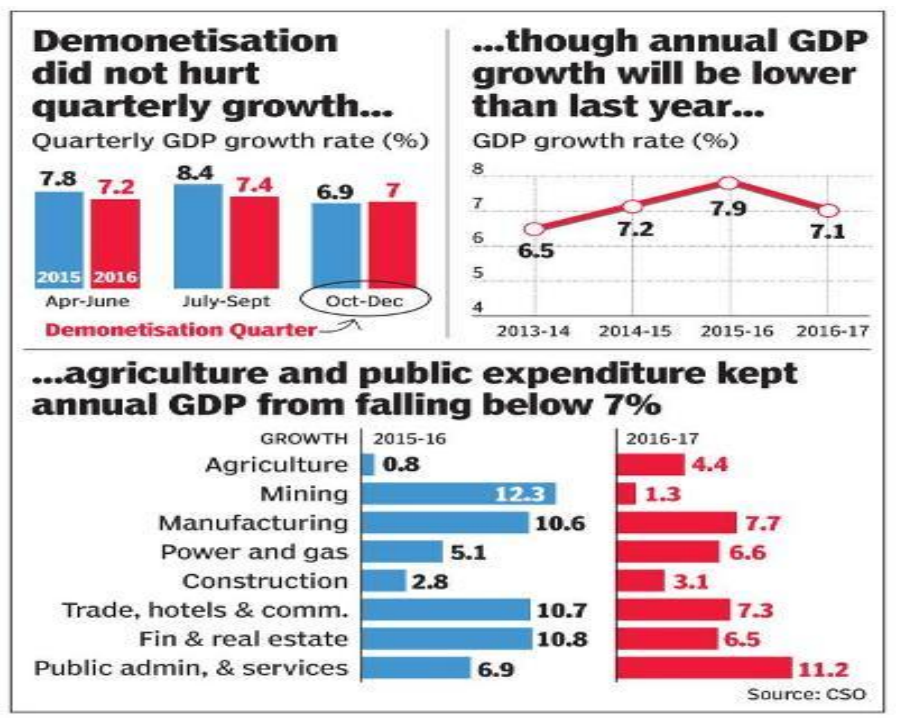

Figure 3 - Demonetisation impact

During the changes that come due to demonetisation, there was a rapid fall in the inclusive growth of the unorganized sector. Mainly the agricultural sector has a positive impact on the GDP due to which the inclusive growth also have been increased, it increase up to 4.4 during 2016-17 as compared to the last year GDP that was 0.8 during 2015-16, this change was came because of suitable weather conditions and rainfall. If we talk about the mining sector, the growth rates have been decreased as compared to the last year. The manufacturing sector has been decline from the previous year due to the demonetisation; almost $2.9 \%$ of the GDP have been fallen. The construction sectors also have been increased in its growth rate. So we finally conclude that demonetisation is good as in all these above sectors.

Under the unorganized sector we found that almost $86 \%$ of the unorganized sector of our country suffers from the problem of inclusive growth which has adverse impact on the unorganized sector due to the demonetisation. Ever since the announcement of

\footnotetext{
${ }^{6}$ http://www.moneycontrol.com/news-topic/centrum-wealth-research/

${ }^{7}$ From the source of library and surveys of demographic analysis

${ }^{8}$ http://www.moneycontrol.com/news/economy/impact-analysisdemonetisationindia_8044821.html
} 
demonetisation, the income of unorganised sector workers has come down drastically - by up to 60 per cent and their work is decreasing day by day.

On the other hand, when we made the analysis, it is to be found that a corrupt system affects poor the most. For instance, take the case of a street vendor. He pays bribes to the police, municipal staff, local mafia, and large shopkeepers - all in cash. Demonetisation has not stopped such bribery. He gets goods from wholesalers on credit or pays in cash.

Within the unorganized sector, there are a proportion of labour-intensive sectors wherein cash was the only way to conduct business. Due to sudden demonetisation announced by the Govt., experts are warning that close to $4,00,000$ jobs may be lost within such sectors.

Thankfully, these job cuts would be temporary - as more currency notes are getting introduced, such labour-intensive sectors would recover gradually and jobs would be back.

But the hard reality is staring us right into the eyes: Out of 32 million people employed by textile and garment industry, one-fifth are daily wagers, who used to get cash as compensation for their work at the end of the day. As there is no currency due to demonetisation, the daily wages for such employees may be reducing. Similarly, $20-15 \%$ of 2.5 lakh workers in leather industry are also impacted.

As per a market study, prices of houses is all set to go down by $30 \%$ across top 42 Indian cities, due to demonetisation.

Due to this market-correction because of demonetisation (which resulted due to loss of black money), approximately Rs 8 lakh crore would be wiped off from the market; majority of which is black money in a bubble)

As per the research, real estate valuation in top 42 Indian cities will drop from Rs 39.55 lakh crore to Rs 31.52 lakh crore in the next 6-12 months. Mumbai will bear the brunt for maximum loss in real estate value (2 lakh crore), followed by Bangalore (Rs 99k crore), and Gurgaon (Rs 79k crore).

During the overall research, the GDP estimates for third quarter of Financial Year 2016-17 have surprised many people. Despite headwinds to growth from demonetisation, GDP growth has been pegged at $7 \%$ in quarter ending December 2016, while overall growth for Financial Year 2016-17 has been estimated at 7.1\%. This is in contrast to various estimates, including the International Monetary Fund's which had expected economic growth to fall to $6 \%$ in the second half of the current fiscal year.

The Indian economy is expected to expand at $7.1 \%$ this financial year after factoring in the impact of demonetisation, the Central Statistics Office (CSO)9 said on Tuesday. Although this is slower than the 7.9\% growth registered in 2015-16, it gives the Narendra Modi government the firepower to defend its decision to scrap old Rs 500 and Rs 1,000 notes, which, according to critics, has been disastrous for the economy.

During October-December 2016, CSO's second advance estimates showed that GDP grew by $7 \%$, compared to $7.4 \%$ in the previous quarter. It maintained the full year growth estimate at the same level $(7.1 \%)$ as the first advance estimate released in early January, which had not factored in the impact of demonetisation.

Black money ${ }^{10}$. During the course of the last month, the objectives of the demonetisation drive have been changing continuously. The initial focus was on curbing black money. However, it soon became apparent that this was a large amount of black money since amounts of money in the form of new currency notes has been recovered during only about $6 \%$ of such money is kept in cash. Consequently, it is not at all surprising that suspicious tax raids.

The above criticism of demonetisation is reinforced by a recent statement of the Revenue Secretary in the Ministry of Finance who has stated that the government expects all scrapped Rs.500 and Rs.1,000 notes to come back to the banking system, which then raises questions about the very purpose of the hugely disruptive demonetisation exercise (IndoAsian News Service (IANS), 2016). It may be remembered that the government expected

\footnotetext{
${ }^{9}$ http://www.csir.res.in

${ }^{10} \mathrm{http} / / /$ economictimes.indiatimes.com/news/politics-and-nation/what-black-money-government-may-be-in-forshock/articleshow/55719794.cms
} 
that, of the Rs. 15.4 trillion of scrapped money, $30 \%$ or Rs. 4.5 trillion was black (that is, this money would not find its way back to the banks). It is now being accepted that at most $10 \%$ of the Rs. 15.4 trillion may be black money.

Some impacts of demonetisation on unorganized sectors:

- Transportation halts. After the demonetisation was announced, about 800,000 truck drivers were affected with scarcity of cash, with around 400,000 trucks stranded at major highways across India were reported. While major highway toll junctions on the Gujarat and Delhi-Mumbai highways also saw long queues as toll plaza operators refused the old banknotes. Nitin Gadkari, the Minister of Transport, subsequently announced a suspension of toll collections on all national highways across India until midnight of 11 November, later extended until 14 November and again until midnight of 18 November, and yet again till 2 December.

- Agriculture, Transactions in the Indian agriculture sector are heavily dependent on cash and were adversely affected by the demonetisation of ₹500 and ₹1,000 banknotes. Due to scarcity of the new banknotes, many farmers have insufficient cash to purchase seeds, fertilisers and pesticides needed for the plantation of Rabi crops usually at the mid-November. Farmers and their unions conducted protest rallies in Gujarat, Amritsar and Muzaffarnagar against the demonetisation as well as against restrictions imposed by the Reserve Bank of India on district cooperative central banks which were ordered not to accept or exchange the demonetized banknotes.

- Dumping of agricultural produce. The demonetisation lead to unavailability of cash to pay for food products. The reduction in demand that turn to crash in the prices of crops. Farmers were unable to recover even the costs of transportation from their fields to the market from the low prices offered. The prices dropped as low as 50 paise per kilo for tomatoes and onions. Some farmers resorted to buying unsold vegetables. Agricultural produce such as vegetables, food grains, sugarcane, milk and eggs were dumped on roads. Some farmers dumped their produce in protest against the government.

- Drop in industrial output. There was a reduction in industrial output as industries were hit by the cash crisis. The Purchasing Managers' Index (PMI) fell to 46.7 in November from 54.5 in October, recording its sharpest reduction in three years. This indicates a slowdown in both, manufacturing and services industries. The PMI report also showed that the reduction in inflation in November was due to shortage in money supply. The growth in eight core sectors such as cement, steel and refinery products, which constitute $38 \%$ of the Index of Industrial Production (IIP), was only to 4.9 percent in November as compared with 6.6 percent in October.

We collect the data through survey, from workers and labourers who were engaged in unorganized sector that includes Small Scale Industry, Cottage Industry and Agriculture Sector allied activities, the survey responded by the researchers who took the survey of almost 1000 peoples who were engaged in unorganized sector.

\section{CONCLUSION}

On the above research we get to know that there is a huge impact of demonetisation over the unorganized sector which reduced the economic growth. From the above analysis of data regarding demonetisation, unorganized sector, Gross domestic Product and the inclusive growth it is hardly to say that the decision of demonetisation may be beneficial for the unorganized sector because the current research shows that there is $86 \%$ of the people who were engaged in the unorganized sector, facing the negative effects due to the decision of demonetisation due to which the Inclusive Growth of unorganized sector also have been declined. Even the government of our country still does not have the proper report of unorganized sector's data as the government has answerable machinery. But the demonetisation may be good for the organized sector of the India economy. 


\section{REFERENCES}

1. Dixit, P. and Lal, R. C. (2016) "Role of Gandhi's Khadi Textile Industry towards Inclusive Growth and Corporate Social Responsibility", Int. J. of Trade and Commerce-IIARTC, Vol. 5, No. 1, pp. 115-120, DOI 10.13140/RG.2.2.36573.26086.

2. Dixit, P., Lal, R. C. (2019), "Inclusive Growth and Social Responsibility - A Critical Analysis of Indian Textile Industry", MERC Global"s International Journal of Management, Vol. 7, Issue 2, pp. 202-210.

3. Dixit, P., Tyagi, A. (2018) "A Study of Downturn Trends of Crude Oil Price - An Economic Advantage for Indian Government and Consumers" 10.13140/RG.2.2.27345.79207.

4. Electronic source: http://debtdiagnosis.com/2016/12/06/demonetisation-is-the-act-ofstripping-a-currency-unit-of-its-status-as-legal-tender/.

5. Electronic source: http://economictimes.indiatimes.com/jobs/why-93-of-indias-workforceis-trapped-in-unorganized-sector/articleshow/16915839.cms.

6. Electronic source: http://economictimes.indiatimes.com/news/politics-and-nation/whatblack-money-government-may-be-in-for-shock/articleshow/55719794.cms.

7. Electronic source: http://siteresources.worldbank.org.

8. Electronic source: http://statisticstimes.com/economy/countries-by-projected-gdp.php.

9. Electronic source: http://www.csir.res.in.

10. Electronic source: http://www.moneycontrol.com/news/economy/impactanalysisdemonetisationindia_8044821.html.

11. Electronic source: http://www.moneycontrol.com/news-topic/centrum-wealth-research/

12. Electronic source: http://www.nistads.res.in/indiasnt2008/t6rural/t6rur5.htm.

13. Electronic source: http://www.oecd.org/inclusive-growth/about/inclusive-citiescampaign/all-on-board-for-inclusive-growth-in-cities-remarks-at-habitat-iii.htm.

14. Pankaj Dixit, Ramyar Rzgar Ahmed, Arvind Kumar Yadav and R. C. Lal (2019). Diversification of economy - an insight into inclusive growth \& food security with special reference to Pakistan's agriculture economy. Asian Journal of Agriculture and Rural Development, 9 (1), 82-98.

15. Pankaj, D., Lal, R. (2019). A Critical Analysis of Indian Textile Industry: An Insight into Inclusive Growth and Social Responsibility. Russian Journal of Agricultural and SocioEconomic Sciences, 88 (4), 53-61. doi:10.18551/rjoas.2019-04.08.

16. Pankaj, D., Ramyar, R. (2019). Diversification of Economy - An Insight into Economic Development with Special Reference to Kurdistan"s Oil Economy and Agriculture Economy. Russian Journal of Agricultural and Socio-Economic Sciences, 85 (1), 395404.

17. Pankaj, D., Ramyar, R. (2019). Economic Diversification: An Insight Into Sustainable And Inclusive Agriculture With Special Reference To Pakistan. Russian Journal of Agricultural and Socio-Economic Sciences, 85 (1), 32-44.

18. Mousa qadrAhmed, D., \& Al, F. A. K. A. K. (2019). Application of Accrual Basis in the Public Sector and its Role in Providing Useful Information Exploratory Study of a Sample of Academic Specialists in the Kurdistan Region of Iraq. Qalaai Zanist Journal, 4 (1).

19. Al, F. A. K. A. K., \& Mousa Qadr Ahmed, D. (2019) The Role Of The Sarbanes-Oxley Act (Sox) In Reducing Agency Costs Exploratory Study Of A Sample Of Auditors In The Kurdistan Region Of Iraq. Qalaai Zanist Journal, 4 (2).

20. Al, F. A. K. A. K. (2019) problems of Internal Auditing in the Educational Sector (A Field study at the private university in Erbil - Iraq). Journal of Arts, Literature, Humanities and Social Sciences, 35 (1). 